\title{
Kajian Potensi Kulit Domba Asal Brebes sebagai Bahan Dasar Produksi Gelatin Halal
}

\section{Study Potential Sheep Skin Origin Brebes for Basic Materials Halal Gelatin Production}

Muhamad Hasdar ${ }^{*}$ dan Yuniarti Dewi Rahmawati

Fakultas Sumberdaya dan Teknologi, Jurusan IImu dan Teknologi Pangan, Universitas Muhadi Setiabudi, Brebes

${ }^{*}$ Korespondensi dengan penulis (hasdarmuhammad@ymail.com)

Artikel ini dikirim pada tanggal 20 Juni 2016 dan dinyatakan diterima tanggal 7 November 2016. Artikel ini juga dipublikasi secara online melalui www.jatp.ift.or.id. Hak cipta dilindungi undang-undang. Dilarang diperbanyak untuk tujuan komersial.

Diproduksi oleh Indonesian Food Technologists® @2017

\begin{abstract}
Abstrak
Pemanfaatan gelatin sudah sangat luas dan sudah menjadi bagian dalam lifestyle masyarakat Indonesia. Namun gelatin yang beredar di Indonesia adalah barang impor, sehingga menimbulkan ketergantungan. Untuk mengurangi ketergantungan diperlukan solusi alternatif produksi gelatin halal. Penelitian ini dilakukan untuk mempelajari sifat fisik dan kimia gelatin kulit domba asal Brebes yang diproduksi menggunakan basa kuat jenis $\mathrm{NaOH}$ dan selanjutnya dibandingkan dengan sifat-sifat gelatin komersial yang distandarkan oleh SNI dan GMIA. Rancangan acak lengkap pola faktorial $3 \times 3$ dengan 3 ulangan digunakan sebagai desain penelitian. Tiga waktu curing $(2,4$, dan 6 jam) dan tiga konsentrasi bahan $(0,1 \%, 0,2 \%, 0,3 \% \mathrm{~b} / \mathrm{v})$ digunakan sebagai perlakuan. Bahan baku berupa kulit domba umur $1-2$ tahun dan $\mathrm{NaOH}$ sebagai bahan curing. Penelitian ini menghasilkan rendemen 13,58 - 15,59\%, kadar air 8,37 - 8,83\%, kadar abu 1,36-1,77\%, kadar lemak 0,63-0,91\%, dan kadar protein $85,51-86,63 \%$. Gelatin yang diproduksi dari kulit domba asal Brebes menggunakan bahan curing jenis $\mathrm{NaOH}$ memiliki sifat yang mirip dengan gelatin komersial yang distandarkan SNI dan GMIA. Produksi gelatin optimum dihasilkan dari penerapan waktu curing 6 jam pada konsentrasi $0.3 \%(b / v)$.
\end{abstract}

Kata kunci: Gelatin Brebes, gelatin halal, konsentrasi $\mathrm{NaOH}$, kulit domba, potensi kulit

\begin{abstract}
Utilization of gelatin is very spacious and has become part of the lifestyle of Indonesian society. However gelatin circulating in Indonesia are imported goods, so addictive. To reduce dependence alternative solution is needed gelatin halal production. This research was conducted to study the physical and chemical properties of gelatin sheepskin from Brebes manufactured using strong base type of $\mathrm{NaOH}$ and then compared with the properties of commercial gelatin standardized by SNI and GMIA. Completely randomized design with $3 \times 3$ factorial design with three replications was used as a research design. Three curing time (2, 4, and 6 hours) and three concentrations of materials $(0.1 \%, 0.2 \%, 0.3 \% \mathrm{w} / \mathrm{v})$ were used as treatments. Raw materials such as lambskin aged 1-2 years and $\mathrm{NaOH}$ as curing materials. This research resulted in the yield of 13.58 to $15.59 \%$, the water content of 8.37 to $8.83 \%$, ash content of 1.36 to $1.77 \%$, the fat content of 0.63 to $0.91 \%$, and protein content 85 , from 51 to $86.63 \%$. Gelatin is produced from sheepskin from Brebes using $\mathrm{NaOH}$ kind curing materials have properties similar to the commercial gelatin standardized SNI and GMIA. Gelatin optimum production resulting from the application curing time of 6 hours at a concentration of $0.3 \%(\mathrm{~W} / \mathrm{V})$.
\end{abstract}

Keywords : Gelatin Brebes, gelatin halal, concentration of $\mathrm{NaOH}$, sheepskin, skin potential

\section{Pendahuluan}

Kebutuhan gelatin di Indonesia dari tahun ke tahun semakin meningkat dengan pesat seiring dengan pertambahan jumlah penduduk dan perubahan lifestyle yang sangat cepat. Didalam kehidupan sehari-hari gelatin telah dimaanfaatkan sebagai bahan makanan (misalnya sebagai agen pembentuk gel, pengental, pengemulsi, pembentuk busa dan edible coating), produk farmasi (misalnya kapsul lunak dan keras), di bidang kedokteran (misalnya sebagai penutup luka) dan dalam banyak aplikasi pada non-pangan (misalnya fotografi). Diperkirakan sekitar $59 \%$ gelatin yang telah dibuat di seluruh dunia digunakan untuk memproduksi makanan, $31 \%$ diaplikasikan pada produk farmasi, $2 \%$ dimanfaatkan untuk industri fotografi, dan sekitar $8 \%$ diaplikasikan dalam bidang lain (GME, 2015). Hal ini disebabkan oleh keunikan dan sifat fungsionalnya yang luas untuk aplikasi dalam berbagai industri dan juga untuk meningkatkan kandungan protein pada bahan pangan. Sebagian besar masyarakat Indonesia tidak faham akan produk gelatin dan manfaat gelatin. Selama ini gelatin yang beredar di Indonesia sudah berbentuk kapsul atau sudah teraplikasi dalam makanan, hal ini dikarenakan Indonesia masih mengimpor gelatin dari Amerika dan Eropa. Akhirnya Indonesia mengalami ketergantungan kesedian gelatin dari tahun ke tahun.

Ketergantungan akan gelatin impor harus dicarikan solusi alternatif, salah satu solusi alternatif yaitu dengan memanfaatkan bahan baku lokal sebagai bahan baku gelatin. By-product ternak domba berupa kulit domba sebagai sumber bahan baku yang sangat berlimpah di Kabupaten Brebes, sehingga bisa menjadi bahan baku lokal yang ketersediaanya mudah untuk didapatkan. Potensi kulit domba sebagai sumber gelatin halal dapat dilihat dari semakin meningkatnya jumlah populasi ternak tersebut di Kabupeten Brebes. Data dari Dinas Peternakan Kabupeten Brebes (2015), 
jumlah populasi ternak domba Kabupaten Brebes tahun 2011 yaitu 168.961 ekor terjadi peningkatan jumlah populasi sejak tahun 2009 yaitu 10.510 ekor. Berat kulit dari domba berkisar $12-15 \%$ dari berat tubuh, sehingga ini menggambarkan potensi besar kulit domba Kabupeten Brebes. Apalagi didukung dengan budaya masyarakat Brebes yang menyukai daging domba sebagai panganan yang diyakini memiliki khasiat khusus.

Pengolahan kulit domba asal Kabupeten Brebes sebagai bahan dasar pembuatan gelatin halal sampai saat ini belum ada kajian, sehingga perlu dilakukan suatu kajian untuk menggali potensi kulit ternak domba lokal asal Kabupeten Brebes sebagai bahan baku gelatin halal. Pada penelitian ini akan memanfaatkan bahan kimia $\mathrm{NaOH}$ sebagai bahan curing (perendam) dan akan dikombinasikan dengan lama waktu curing.

\section{Materi dan Metode \\ Materi}

Bahan utama yang digunakan dalam penelitian ini yaitu kulit domba yag berasal dari Kabupaten Brebes yang berumur 1 - 2 tahun. Bahan curing yang digunakan yaitu $\mathrm{NaOH}$ dengan konsentrasi $0,1 \%, 0,2 \%$, dan $0,3 \%$. Bahan lain yang digunakan yaitu aquades dan air. Peralatan yang digunakan dalam pembuatan gelatin adalah timbangan analitik, saringan, hot plate, termometer, gelas ukur, gelas beaker, cawan petri, labu ukur, erlemeyer.

\section{Metode}

Penelitian berlansung selama periode Juli November 2015. Penelitian ini meliputi proses pembuatan gelatin dan analisa karakteristik proksimat (AOAC, 2005) gelatin meliputi kadar protein, kadar lemak, kadar air, dan kadar abu, serta analisa rendemen.

\section{Proses Pembuatan Gelatin}

Kulit domba segar yang didapatkan dari rumah pemotongan hewan di Kabupaten Brebes terlebih dahulu dipisahkan antara kulit dan wool dengan menggunakan silet kerok yang tajam. Kemudian dilakukan penmbuangan sisa-sisa daging atau lemak yang masih menempel pada kulit dengan menggunakan pisau tajam. Lalu selanjutnya dicuci dengan air bersih. Kulit yang telah bersih dari wool dan sisa-sisa daging/lemak ditiriskan agar air tidak banyak tertinggal dikulit. Kemudian dilakukan penimbangan kulit segar lalu di kulit segar dikecilkan ukurannya menjadi $\pm 2 \times 2 \mathrm{~cm}$. Selanjutnya direndam pada larutan $\mathrm{NaOH} 0.1 \%, 0.2 \%$ dan $0.3 \%(\mathrm{~b} / \mathrm{v})$ dengan lama waktu perendaman/curing yang berbeda yaitu selama 2 jam, 4 jam dan 6 jam. Hasil curing kulit domba kemudian di ekstrak dengan menggunakan metode hot treatment dengan temperatur $50-55^{\circ} \mathrm{C}$ yang dilakukan secara bertingkat selama 4 jam, 3 jam, dan 2 jam. Selanjutnya untuk mempermudah proses pengeringan, gelatin di cetak dan dikeringkan dalam kardus yang diberi 3 lampu dengan daya sebesar 10 watt, metode pengeringan ini memodifikasi proses pengeringan yang telah dilakukan oleh Juliasti et al., (2014).

\section{Analisis Statistik}

Penelitian ini menggunakan Rancangan Acak Lengkap (RAL) pola faktorial $3 \times 3$, bahan curing yang digunakan yaitu $\mathrm{NaOH}(\mathrm{g} / \mathrm{l})$, sebagai faktor pertama yaitu lama waktu konsentrasi bahan curing $(0,1 \%$, $0,2 \%$, dan $0,3 \% \mathrm{~b} / \mathrm{v}$ ) dan faktor kedua yaitu lama waktu curing (2 jam, 4 jam, dan 6 jam). Masing-masing perlakuan diulang sebanyak tiga (3) kali. Analisis penelitian ini menggunakan metode analisis ragam. Semua data yang diperoleh, kemudian dianalisis dengan metode One-Way ANOVA pola faktorial menggunakan SPSS 17.0 Statistic Software. Level signifikan yang ditetapkan sebesar $a=0,05$.

\section{Hasil dan Pembahasan \\ Rendemen}

Rendemen merupakan ukuran dari persentase berat gelatin yang didapat dari konversi kolagen pada kulit. Semakin besar rendemen yang dihasilkan, menunjukkan metode yang dilakukan semakin efisien dan efektif. Persentase rendemen gelatin kulit domba asal Brebes dengan perlakuan perbedaan konsentrasi $\mathrm{NaOH}$ dan lama waktu curing tampil pada Tabel 1.

Tabel 1. Rendemen (\%) gelatin kulit domba asal Brebes

\begin{tabular}{ccccc}
\hline \multirow{2}{*}{ Lama Waktu Curing } & \multicolumn{3}{c}{ Konsentrasi NaOH } & Rata - rata \\
\cline { 2 - 4 } & $0.1 \%$ & $0.2 \%$ & $0.3 \%$ & $14,07 \pm 0,08^{\mathrm{c}}$ \\
\hline 2 jam & $13,58 \pm 0,05$ & $14,15 \pm 0,08$ & $14,46 \pm 0,12$ & $14,32 \pm 0,07^{\mathrm{c}}$ \\
4 Jam & $14,14 \pm 0,06$ & $14,32 \pm 0,06$ & $14,49 \pm 0,08$ & $14,77 \pm 0,53^{\mathrm{d}}$ \\
6 Jam & $14,21 \pm 0,17$ & $14,52 \pm 0,21$ & $15,59 \pm 1,20$ & $14,85 \pm 0,47^{\mathrm{b}}$ \\
\hline Rata - rata & $13,98 \pm 0,09^{\mathrm{a}}$ & $14,33 \pm 0,12^{\mathrm{a}}$ & 14. &
\end{tabular}

Keterangan : notasi yang berbeda pada kolom yang sama menunjukkan perbedaan yang nyata $(\mathrm{P}<0,05)$

Tabel 2. Kadar air (\%) gelatin kulit domba asal Brebes

\begin{tabular}{ccccc}
\hline \multirow{2}{*}{ Lama Waktu Curing } & \multicolumn{3}{c}{ Konsentrasi NaOH } & Rata-rata \\
\cline { 2 - 4 } & $0,1 \%$ & $0,2 \%$ & $0,3 \%$ & $8,76 \pm 0,38^{\mathrm{ns}}$ \\
2 Jam & $8,73 \pm 0,52$ & $8,73 \pm 0,25$ & $8,83 \pm 0,36$ & $8,55 \pm 0,08^{\mathrm{ns}}$ \\
4 Jam & $8,71 \pm 0,22$ & $8,54 \pm 0,01$ & $8,41 \pm 0,01$ & $8,48 \pm 0,26^{\mathrm{ns}}$ \\
6 Jam & $8,43 \pm 0,19$ & $8,37 \pm 0,28$ & $8,63 \pm 0,32$ & \\
\hline Rata-rata & $8,62 \pm 0,31^{\mathrm{ns}}$ & $8,55 \pm 0,18^{\mathrm{ns}}$ & $8,62 \pm 0,23^{\mathrm{ns}}$ & \\
\hline
\end{tabular}


Berdasarkan Tabel 1, terlihat bahwa faktor konsentrasi $\mathrm{NaOH}$ dan faktor lama curing menunjukkan perbedaan yang nyata $(P<0,05)$, namun tidak terdapat interaksi dari konsentrasi $\mathrm{NaOH}$ dan faktor lama curing. Hasil uji Duncan menunjukkan bahwa semakin meningkatnya konsentrasi $\mathrm{NaOH}$ dan semakin lama waktu curing akan meningkatkan rendemen gelatin. Cho et al. (2006) menyatakan bahwa rendemen gelatin akan meningkat secara kontinyu seiring dengan besarnya kenaikan konsentrasi bahan curing. Penggunaan bahan kimia yang tepat akan membantu memecah ikatan hidrogen dalam gel yang terhidrolisis. Banyaknya gel dari ikatan hidrogen yang dipecah oleh bahan kimia curing akan memudahkan larutnya kolagen dalam air panas, sehingga memaksimalkan perolehan gelatin (Choa et al., 2005).

Konsentrasi $\mathrm{NaOH}$ yang tinggi dapat memecah ikatan peptida pada molekul protein kolagen kulit dengan baik, sehingga rendemen yang dihasilkan pula lebih banyak. Rendemen gelatin yang dihasilkan dalam proses produksi tergantung pada proses yang dilakukan terhadap protein kolagen (Kasankala et al., 2007). Hal ini disebabkan oleh banyaknya $\mathrm{NaOH}$ yang dapat mempercepat laju hidrolisis sehingga proses transformasi kolagen menjadi gelatin akan semakin banyak (Zhou dan Regenstein, 2004).

Berdasarkan Tabel 1 terlihat bahwa secara ratarata terjadi peningkatan nilai rendemen dengan bertambahnya waktu curing dan konsentrasi $\mathrm{NaOH}$. Rata-rata rendemen yang dihasilkan pada peneltian ini yaitu $13,58 \%$ - 15,59\%, dapat dikatakan rendemen penelitian ini lebih baik jika dibandingkan dengan penelitian Said et al., (2011a) dengan rata-rata rendemen $12,37 \%-14,69 \%$.

\section{Kadar Air}

Persentase kadar air gelatin kulit domba asal Brebes dengan perlakuan perbedaan konsentrasi $\mathrm{NaOH}$ dan lama waktu curing ditampilkan pada Tabel 2. Berdasarkan Tabel 2. Menunjukkan bahwa konsentrasi $\mathrm{NaOH}$, lama waktu curing, dan interaksi konsentrasi $\mathrm{NaOH}$ dengan lama waktu curing tidak memberikan pengaruh terhadap kadar air gelatin. Pada penelitian ini lama pengeringan 24 jam dengan temperatur $40-60^{\circ} \mathrm{C}$, sehingga diperoleh kualitas gelatin dengan kadar air yang sama. Metode pengeringan sangat berpengaruh pada produk yang dihasilkan. Pada penelitian ini menggunakan pengeringan sederhana dengan memanfaatkan kardus yang diberi lampu bolham dan dikeringkan selama 24 jam, temperatur pada ruangan kardus berkisar 40 $60^{\circ} \mathrm{C}$. Pada pengukuran kadar air, air yang terukur adalah jenis air yang berada dalam bentuk terikat secara fisik dan air yang berada dalam bentuk bebas pada gelatin. Alat, temperatur dan lama pengeringan merupakan faktor yang mempengaruhi nilai kadar air bahan hasil pengeringan gelatin. Temperatur yang terlalu tinggi akan mengakibatkan gelatin menjadi mudah retak dan patah (Schrieber dan Gareis, 2007). Kadar air pada gelatin kering akan yang sangat mempengaruhi aktivitas metabolisme seperti enzim, aktivitas mikroba, dan aktivitas kimiawi, misalnya terjadinya ketengikan dan reaksi-reaksi non enzimatik, sehingga dapat menimbulkan perubahan sifat dan nilai gizi bahan pangan (Astawan dan Aviana, 2003).

Kadar Air yang dihasilkan oleh penelitian ini

Tabel 3. Kadar abu (\%) gelatin kulit domba asal Brebes

\begin{tabular}{ccccc}
\hline \multirow{2}{*}{ Lama Waktu Curing } & \multicolumn{3}{c}{ Konsentrasi NaOH } & \multirow{2}{*}{ Rata - rata } \\
\cline { 2 - 4 } & $0,1 \%$ & $0,2 \%$ & $0,3 \%$ & $1,54 \pm 0,13^{\mathrm{abc}}$ \\
2 Jam & $1,59 \pm 0,10$ & $1,59 \pm 0,19$ & $1,45 \pm 0,10$ & $1,66 \pm 0,18^{\mathrm{b}}$ \\
4 Jam & $1,55 \pm 0,27$ & $1,67 \pm 0,18$ & $1,77 \pm 0,11$ & $1,44 \pm 0,11^{\mathrm{c}}$ \\
6 Jam & $1,47 \pm 0,15$ & $1,36 \pm 0,13$ & $1,49 \pm 0,06$ & $1,57 \pm 0,09^{\mathrm{ns}}$ \\
\hline Rata-rata & $1,54 \pm 0,17^{\text {ns }}$ & $1,54 \pm 0,17^{\text {ns }}$ & 1,54 & \\
\hline
\end{tabular}

Ket : notasi yang berbeda pada kolom yang sama menunjukkan perbedaan yang nyata $(P<0,05)$

$n s=$ non significant

Tabel 4. Kadar lemak (\%) gelatin kulit domba asal Brebes

\begin{tabular}{|c|c|c|c|c|}
\hline \multirow{2}{*}{ Lama Waktu Curing } & \multicolumn{3}{|c|}{ Konsentrasi $\mathrm{NaOH}$} & \multirow{2}{*}{ Rata - rata } \\
\hline & $0,1 \%$ & $0,2 \%$ & $0,3 \%$ & \\
\hline 2 Jam & $0,91 \pm 0,05$ & $0,79 \pm 0,09$ & $0,66 \pm 0,05$ & $0,79 \pm 0,06^{\mathrm{ns}}$ \\
\hline 4 Jam & $0,84 \pm 0,02$ & $0,79 \pm 0,04$ & $0,74 \pm 0,04$ & $0,79 \pm 0,29^{\mathrm{ns}}$ \\
\hline $6 \mathrm{Jam}$ & $0,71 \pm 0,04$ & $0,73 \pm 0,02$ & $0,63 \pm 0,03$ & $0,69 \pm 0,09^{n s}$ \\
\hline Rata-rata & $0,82 \pm 0,03^{\mathrm{ns}}$ & $0,77 \pm 0,05^{\mathrm{ns}}$ & $0,68 \pm 0,04^{n s}$ & \\
\hline
\end{tabular}

Ket : $n s=$ non significant

Tabel 5. Kadar protein (\%) gelatin kulit domba asal Brebes

\begin{tabular}{ccccc}
\hline \multirow{2}{*}{ Lama Waktu Curing } & \multicolumn{3}{c}{ Konsentrasi NaOH } & \multirow{2}{*}{ Rata-rata } \\
\cline { 2 - 4 } & $0,1 \%$ & $0,2 \%$ & $0,3 \%$ & $86,18 \pm 0,35^{\mathrm{ns}}$ \\
2 Jam & $85,90 \pm 0,29$ & $86,30 \pm 0,36$ & $86,35 \pm 0,41$ & $85,99 \pm 0,67^{\mathrm{ns}}$ \\
4 Jam & $85,51 \pm 0,99$ & $86,32 \pm 0,36$ & $86,13 \pm 0,66$ & $86,36 \pm 0,57^{\mathrm{ns}}$ \\
6 Jam & $86,08 \pm 1,23$ & $86,38 \pm 0,42$ & $86,63 \pm 0,07$ & \\
\hline Rata-rata & $85,83 \pm 0,84^{\mathrm{ns}}$ & $86,33 \pm 0,38^{\mathrm{ns}}$ & $86,37 \pm 0,38^{\mathrm{ns}}$ & \\
\hline
\end{tabular}

Ket : $n s=$ non significant 
masih yaitu $8,37-8,83 \%$ dan masih mengikuti standar yang ditetapkan oleh standar nasional Indonesia No. 06-3735 -1995 adalah maksimum 16\%. Selain itu, kadar air gelatin hasil penelitian ini juga memenuhi standar gelatin untuk bahan pangan (14\%) maupun standar untuk bahan farmasi (14\%). Hal ini menunjukan proses pengeringan yang dilakukan sudah tepat. Pengeringan dengan metode sederhana ini mampu mengevaporasi air pada cairan kolagen hasil esktrasi kulit domba.

Kadar air pada penelitian ini hampir mirip dengan kadar air gelatin yang dihasilkan oleh penelitian Amertaningtyas et al., (2014) yaitu 8,69 - 9,29\%, hal ini disebabkan karena bahan curing yang digunakan berasal dari golongan alkali dan bahan baku yang digunakan juga hampir mirip yaitu kulit ternak kecil. Namun penelitian ini masih lebih baik jika dibandingkan dengan penelitian Juliasti et al., (2015) yang menghidrolisis tulang kaki kambing dengan asam klorida sehingga menghasilkan gelatin dengan kadar air $13,20-14,67 \%$.

\section{Kadar abu}

Kadar abu pada pangan menunjukan adanya zat anorganik atau mineral lain yang menjadi sisa hasil pembakaran. Kandungan abu dan komposisinya tergantung pada jenis bahan dan metode yang digunakan dalam pengabuan. Selain itu keadaan abu juga menunjukkan kemurnian bahan dan ketepatan proses pembuatannya. Kadar abu gelatin berbahan baku domba Brebes ditunjukan pada Tabel 3.

Berdasarkan hasil analisis ragam yang disajikan pada Tabel 3. menunjukkan bahwa lama waktu curing memberikan pengaruh pada yang signifikan pada kadar abu. Hal ini disebabkan oleh kemampuan $\mathrm{NaOH}$ untuk melonggarkan ikatan molekul protein, perendaman yang lebih lama akan memberikan peluang pada ikatan molekul protein menjadi longgar sehingga memudahkan proses hidrolisis. Hal ini sejalan dengan penelitian Puspawati et al., (2012) yang menyatakan bahwa perendaman kulit kaki ayam yang lama (3 hari) akan menyebabkan tropokolagen mengalami swelling (mengembang) yang belebihan yang mengakibatkan rantai tropokolagen akan larut dalam larutan $\mathrm{NaOH}$ sehingga menurunkan rendemen ekstrak gelatin.

Berdasarkan sajian Tabel 3. menunjukkan bahwa konsentrasi $\mathrm{NaOH}$ tidak berpengaruh nyata pada kadar abu. Hal ini disebabkan konsentrasi $\mathrm{NaOH}$ yang digunakan pada setiap perlakuan memliliki interval yang tidak begitu lebar, sehingga kadar abu yang dihasilkan berdasarkan konsentrasi $\mathrm{NaOH}$ tidak berbeda antar perlakuan. Menurut Gomes-Guillen et al. (2002) bahwa besar kecilnya kadar abu gelatin sangat dipengaruhi oleh proses perendaman dan konsentrasi bahan kimia, sehingga bahan kimia yang berkonsentrasi tinggi memungkinkan terjadinya pembengkakan kulit yang berlebihan menyebabkan hilangnya molekul protein dan mengendapnya mineral yang tidak dibutuhkan. Mineral yang tidak dibutuhkan ini akan menyebabkan kadar abu yang tinggi pada gelatin (Puspawati et al., 2012). Faktor pendukung yang menyebabkan kadar abu menjadi tinggi adalah preparasi awal penyiapan bahan baku. Bahan baku yang masih belum bersih akan mengakibatkan kadar abu makin meningkat. Faktor lain yang meyebabkan kadar abu pada gelatin tinggi yaitu proses penyaringan kolagen yang tidak tepat. Penyaringan yang meninggalkan endapan akan menimbulkan kadar abu yang tinggi.

Kadar abu gelatin dari penelitian ini berkisar antara 1,36 - 1,77\% masih lebih baik dari penelitian Sugihartono et al., (2015) yang menghidrolisis kulit pikel domba yang menghasilkan kadar abu yang tinggi yaitu $1,75-4,94 \%$. Semua nilai kadar abu gelatin yang diperoleh dari penelitian ini memenuhi standar mutu Standar Nasional Indonesia 06-3735-1995 yaitu kadar abu gelatin maksimum $3,25 \%$.

\section{Kadar Lemak}

Kadar lemak dalam produk gelatin berkaitan langsung dengan sumber bahan baku yang digunakan. Gelatin yang diproduksi dari bahan baku yang mengandung kadar lemak tinggi cenderung akan menghasilkan produk gelatin dengan kadar lemak yang tinggi pula. Nilai rataan kadar lemak gelatin yang diproduksi selengkapnya disajikan pada Tabel 4 .

Berdasarkan hasil analisis ragam yang disajikan pada Tabel 4. menunjukkan bahwa kadar lemak gelatin kulit domba tidak memberikan pengaruh yang signifikan di setiap perlakuan baik perlakuan konsentrasi $\mathrm{NaOH}$, lama waktu curing, maupun interaksi antar kedua faktor. Hal ini dipengaruhi oleh bahan baku yang dipakai mempunyai umur yang relatif sama yaitu $1-2$ tahun dengan jenis kelamin jantan. Selain itu proses penghilangan lemak saat pengulitan pun memberikan dampak yang sama pada kadar lemak gelatin yang dihasilkan. Namun jika dilihat dari rata-rata kadar lemak dari semua perlakuan terjadi penurunan pada variabel lama waktu curing dan variabel konsentrasi $\mathrm{NaOH}$ walaupun yang tidak signifikan. Penurunan kadar lemak yang tidak signifikan ini diakibatkan oleh kemampuan basa $\mathrm{NaOH}$ yang sedikit demi sedikit dapat mengurai protein dan lemak yang terkandung dalam kulit. Hal ini dapat dilihat saat proses ekstraksi dengan pemanasan, lemak akan keluar dari kulit dan pengapung dipermukaan. Saat lemak yang mengapung dipermukaan harus segera dipisahkan dan diambil dengan cara manual, sehingga protein kolagen hasil ekstraksi tidak mengandung lemak yang berlebihan.

Kadar lemak gelatin pada penelitian ini yaitu 0,63 $0,91 \%$ masih lebih tinggi dari kadar lemak gelatin yang dihasilkan oleh Said et al., (2011b) yaitu berkisaran $0,23-0,35 \%$ hal ini disebabkan oleh penggunaan bahan baku yang berbeda. Kadar lemak domba yang dipelihara di daerah pantura lebih tinggi dibandingkan dengan kadar lemak kambing yang dipelihara dengan cara di umbar di pegunungan. Disisi lain kadar lemak gelatin hasil penelitian ini juga lebih rendah dibanding kadar lemak gelatin komersial. Rendahnya persentase kadar lemak pada gelatin yang dihasilkan kemungkinan disebabkan temperatur ekstraksi yang digunakan juga sangat rendah yaitu $50-60^{\circ} \mathrm{C}$ dan pemisahan secara manual antara larutan kolagen dengan lemak saat proses ekstraksi. Kisaran nilai kadar lemak ini cukup 
baik, karena sebagian besar tidak melebihi $5 \%$ yang merupakan batasan nilai maksimal untuk persyaratan mutu gelatin GMIA.

\section{Kadar Protein}

Gelatin sebagai salah satu jenis protein konversi yang dihasilkan melalui proses hidrolisis kolagen, sehingga kadar protein yang terkandung di dalamnya sangat tinggi. Tingkat pelarutan protein kolagen dipengaruhi oleh waktu dan konsentrasi bahan curing yang digunakan. Kadar protein gelatin komersial yang beredar dipasaran berkisar 85 - 90\% (Schrieber dan Gareis, 2007). Kadar protein dari penelitian ini disajikan pada Tabel 5.

Berdasarkan Tabel 5. terlihat terjadi peningkatan rata-rata protein pada faktor konsentrasi $\mathrm{NaOH}$ walaupun tidak signifikan. Hal ini dapat menggambarkan bahwa kadar protein dengan menggunakan konsentrasi $\mathrm{NaOH} 0,1 \%$ - 0,3\% tidak jauh berbeda walau terjadi peningkatan. Berdasarkan hasil yang diperoleh kadar protein yang tertinggi diperoleh pada gelatin yang di-curing selama 6 jam dengan konsentrasi $\mathrm{NaOH} \quad 0,3 \%$. Kombinasi ini merupakan kombinasi terbaik dalam perolehan gelatin karena kadar protein yang tinggi berkaitan langsung dengan sifat-sifat fisik dari gelatin tersebut seperti kekuatan gel dan viskositas. Pada proses pembentukan biopolimer alami seperti gelatin, maka sifat-sifat pendukung seperti keluatan gel dan viskositas sangat diperlukan untuk memperbaiki struktur dan kemampuan biopolimer untuk menghambat transfer massa dari lingkungan, namun dengan syarat kualitas kadar proteinya pun lebih baik (Chen, 1995). Selain itu kadar protein yang baik dari gelatin diharapkan akan memberikan sumbangan tambahan zat gizi terhadap produk pangan olahan selanjutnya.

Menurut Schrieber dan Gareis, (2007) bahwa peningkatan kadar protein berkaitan dengan perubahan jumlah struktur ikatan asam amino yang menyusun molekul protein kolagen yaitu -Ala-Gly-Pro-Arg-Gly-Glu4Hyp-Gly-Pro-. Peningkatan konsentrasi molekul protein kolegen akan menyebabkan semakin banyak ikatan asam amino yang terpecah sehingga semakin banyak protein yang larut pada saat dilakukan proses ekstraksi. Peningkatan waktu curing dan konsentrasi bahan menyebabkan serabut kolagen menyusut dan mudah untuk larut saat ekstraksi yang memudahkan pembentukan gelatin (Astawan dan Aviana, 2003).

Kadar protein hasil penelitian ini yaitu 85,51 $86,63 \%$, masih lebih rendah dibandingkan oleh penelitian Said et al. (2011c) yaitu 89,37 - 90,74\%, hal ini disebabkan oleh penggunaan bahan kimia yang berbeda. Biasanya bahan kimia asam lebih baik dari pada bahan kimia basa, sehingga lebih disukai namun bahan kimia asam harganya lebih mahal. Kadar protein penelitian ini masih memenuhi standar yang ditetapkan GMIA (2015), yaitu antara 84 - 90\%.

\section{Kesimpulan}

Berdasarkan hasil penelitian yang diperoleh, Kualitas gelatin berbahan baku domba asal Brebes yang di curing dengan $\mathrm{NaOH}$ memiliki kualitas yang baik sesuai standar SNI dan GMIA. Kualitas gelatin terbaik yaitu rendemen 15,59, kadar air 8,37\% , kadar abu $1,36 \%, \mathrm{pH} 6,01$, kadar lemak $0,63 \%$, dan kadar protein $86,63 \%$. Gelatin terbaik dari penelitian ini yaitu pada perlakuan konsentrasi $\mathrm{NaOH} 0,3 \%$ dan lama waktu curing 6 jam yang menghasilkan rendemen $15,59 \%$.

\section{Ucapan Terimakasih}

Penulis mengucapkan terima kasih kepada Bappeda Kabupaten Brebes melalui Riset Unggulan Daerah tahun 2015 yang telah memberi dukungan pendanaan terhadap penelitian ini.

\section{Daftar Pustaka}

Amertaningtyas, D., Thohari, I., Purwadi, Radiati, L.A., Rosyidi, D., dan Jaya F. 2014. Pengaruh Konsentrasi Larutan Kapur Sebagai Curing Terhadap Kualitas Fisiko-Kimia dan Organoleptik Gelatin Kulit Kambing Peranakan Ettawah (PE), Jurnal IImu-IImu Peternakan, 24 (2), pp.1-7.

Association of Official Analytical Chemists (AOAC). 2005. Official Methods of Analysis of The Association of Analytical Chemist. AOAC, Inc, Virginia.

Astawan, M dan Aviana ,T. 2003. Pengaruh Jenis Larutan Serta Metode Pengeringan Terhadap Sifat Fisik, kimia dan Fungsional Gelatin Dari Kulit Ikan Cucut, Jurnal Teknologi dan Industri Pangan, 14(1), pp.7-13.

Badan Standarisasi Nasional. 1995. SNI 06-3735-1995. Mutu dan Cara Uji Gelatin, Jakarta.

Chen, H. 1995. Functional Properties And Applications of Edible Films Made of Milk Proteins, Journal of Dairy Science, 78(11), pp. 2563-2583.

Cho, S-H., Jahncke, M.L., Chin, K-B., and. Eun, J-B. 2006. The ffect of Processing Conditions on The Properties of Gelatin From Skate (Raja kenojei) Skin, Food Hydrocolloids, 20 (6), pp. 810-816.

Choa, S.M., Gub, Y.S., and Kima, S.B. 2005. Extracting Optimization and Physical Properties of Yellowfin Tuna (Thunnus albacares) Skin Gelatin Compared to Mammalian Gelatins, Food Hydrocolloids, 19, pp. 221-229.

Dinas Peternakan Kabupaten Brebes. 2015. Data Populasi Domba Kabupeten Brebes. http://www.dinnak.web.id/p/blogpage_318.html. [Diakses tanggal 25 April 2015].

GME. 2015. Gelatine.org Market Data 2011. Gelatine Manufacture of Europe. http://www.gelatine.org/en/gelatine/history/html. [Diakses 27-11-15]

GMIA. 2015. Gelatin Manufacturer Institute of America 2015, The Gelatin Handbook. http://www.gelatingmia.com/gelatinhandbook.html. [Diakses 2711-15].

Gomes-Guillen, M.C., J. Turney, M.D. Fernandez Diaz, N. Ulmo, M.A. Lizarbe and P. Montero. 2002. 
Structural and Physical Properties of Gelatin Extracted From Different Marine species : Comparative Study. Food Hydrocolloids, 16 (1), pp. 25-34

Juliasti, R., Legowo, A.M., dan Pramono, Y.B. 2015. Pemanfaatan Limbah Tulang Kaki Kambing Sebagai Sumber Gelatin Dengan Perendaman Menggunakan Asam Klorida, Jurnal Aplikasi Teknologi Pangan 4(1), pp.5-10.

Kasankala, L.M., Xue, Y., Weilong, Y., Hong, S.D dan Q, He. 2007. Optimization of gelatine Extraction From Grass Carp (Catenopharyngodon idella) Fish Skin by Response Surface Methodology, Bioresource Technology, 98(17), pp,3338-3343.

Puspawati, N.M., Simpen, I.N., dan Miwada, I.N.S. 2012. Isolasi Gelatin Dari Kulit Kaki Ayam Broiler Dan Karakterisasi Gugus Fungsinya Dengan Spektrofotometri FTIR, Jurnal Kimia, 6 (1), pp. 79-87

Said, M.I., Likadja, J.C. dan Hatta M. 2011a, Pengaruh Waktu Dan Konsentrasi Bahan Curing Terhadap Kuantitas Dan Kualitas Gelatin Kulit
Kambing Yang Diproduksi Melalui Proses Asam. JITP, 1(2), pp.199-128.

Said, M.I., Triatmojo, S., Erwanto, Y., dan Fudholi, A. 2011b, Karakteristik Gelatin Kulit Kambing Yang Diproduksi Melalui Proses Asam dan Basa. Agritech, 31(3), pp. 190-200.

Said, M.I., Triatmojo, S., Erwanto, Y., and Fudholi, A. 2011c, Gelatin Properties of Goat Skin Produced by Calcium Hydroxide as Curing Material, Media Peternakan, 34 (3), pp. 184189

Schrieber, R., and Gareis, H. 2007. Gelatine Handbook, Theory and Industrial Practice, WILEY-VCH Verlag GmbH \& Co.KGaA, Weinheim.

Sugihartono, Sutyasmi, S., dan Prayitno. 2015. Pemanfaatan Trimming Kulit Pikel Sebagai Flokulan Melalui Hidrolisis Kolagen Menggunakan Basa Untuk Penjernihan Air, Majalah Kulit, Karet, Dan Plastik, 31(1), pp. 3744.

Zhou, P. and Regenstein, J.M. 2004. Optimization of Extraction Conditions for Pollock Skin Gelatin, Journal of Food Science, 69(5), pp.393-398. 